\title{
IAMJ
}

INTERNATIONAL

AYURVEDIC

MEDICAL JOURNAL

\section{CONCEPTS OF MAMSA MARMA - A REVIEW ARTICLE}

\section{$\underline{\text { Mahesh Kumar }}^{1}, \underline{\text { Priyanka }}^{2}, \underline{\text { S. S. Gupta }}^{3}$}

${ }^{1}$ Mahesh Kumar, P.G (Scholar), Dept.of Rachana Sharir (Anatomy), Government Ayurvedic College and Hospital, Kadamkuan, Patna (Bihar)

${ }^{2}$ Priyanka, Assistant Professor, Dept.of Rachana Sharir (Anatomy), Government Ayurvedic College and Hospital, Kadamkuan, Patna (Bihar)

${ }^{3}$ Prof. S.S. Gupta, Professor and Head, Dept.of Rachana Sharir (Anatomy), Government Ayurvedic College and Hospital, Kadamkuan, Patna, (Bihar)

Corresponding Author: mahesh.umar@rediffmail.com

https://doi.org/10.46607/iamj4409092021

(Published Online: September 2021)

Open Access

(C) International Ayurvedic Medical Journal, India 2021

Article Received: 29/08//2021 - Peer Reviewed: 04/09/2021 - Accepted for Publication: 05/09/2021

\section{Check for updates}

\section{ABSTRACT}

Ayurveda is one of the most ancient medical science in the world. Ayurveda is known as the science of life. It is not only medical science, but it is also a way of life. In Ayurvedic literature many Aacharyas (Sage) like Atreya Punarvashu,Dhanvantari,Sushruta,Charaka,Vagbhata and other commentators of samhitas (Ancient iterature) have made, its importance the knowledge of Sharir (body) to have undoubtedly for the sake of knowledge. In Ayurveda, Rachana sharir is a very important part of this science to make a person a good physician or a good surgeon. In Rachana Sharir, Marma sharir is very important topic. By knowing this, a person may become a good physician or surgeon. Marma sharir and its practical application are very important during surgery and to understand the injury at marma site, their prognosis and possible prevention is necessary. Inside the body, there is a specific anatomical location which is called a vital point.

Keywords: Mamsa (muscle), marma (vital part), jivsthan (life site), Parinam (result), pariman (dimension) 


\section{INTRODUCTION}

Marma (vital part) is the site or point where trauma or injury causes death or is nearer to death. In "prateykmarmanirdeshrishar" Sushruta (father of surgery) has advocated Saptotaram marm satam" i.e, the Number of marma is 107. Marma point or site is also called jivsthan ${ }^{l}$. It means that pran (life) is present in jivsthan. Being a good surgeon or physician, it is necessary to know a complete and detailed knowledge of Rachana Sharir (Anatomy). Marma is classified into many groups based on Shadang (six parts) Sharir (body), structure, parimana (dimension) and parinama (result). Structural marmas are Mamsa (muscle), Sira (artery / vein), Snayu (ligament), Asthi (bone) and Sandhi (joint). Here we will discuss the Mamsa marma. It is eleven in number as Talhridya-4, Indrabasti-4, Guda-1, Stanrohit-2.

\section{AIMS AND OBJECTIVES -}

(1) There is nothing a detailed description of Mamsa (muscle) marma in Ayurvedic literature.

(2) There is no sufficient knowledge for the Modern point of view.

(3) In the present study, it is necessary to get a clear concept of Mamsa marma of the body in terms of the modern view. So I will try to do compare of Mamsa marma of Ayurvedic knowledge to the Modern view. MATERIAL AND METHODS-

It is necessary to know about the complete and detailed knowledge of Mamsa marma as described in Ayurvedic literature. That knowledge may be compared with modern science. The sign and symptoms of Mamsa marma which occur due to injury or trauma may or may not be similar. So I have chosen the topic of Mamsa marma to compare Ayurvedic knowledge with modern science.

\section{DISCUSSION}

Dalhan (Sushruta's Tikakara or commentator) said Maryanti iti marmani ${ }^{3}$ i.e. Marma is a site where an injury causes death.This site is called jivsthan ${ }^{4}$ (life site). Marma sthan is also called a vital weak $\operatorname{spot}^{5 .}$ of the body. Jivsthan (life site or vital part) is that site that includes pran. Pran is life. There is 12 in number in Ayurveda as agni (fire), som (cold), vayu (air), satv (mind), raj (royal), tam (vengeful) and five senses shabd (sound), sparsh (touch), rupa (shape), rasa (plasma), gandha (smell) and bhutatma (immortal). If the contents of the body are damaged or changed, man will die or nearer to die. Mamsa marma is one of the types of structural classification of marma ${ }^{6}$ as talhridaya, indrabasti, guda and stanrohit. After trauma on talhridaya marma causes pain and pain ends into death. If an injury on indrabasti marma results excessive bleeding and ultimately death occurs. Guda is the root of Sharir (body). If an injury is in Guda, man will die immediately due to severe bleeding. Stanrohit is a type of Mamsa marma who lie above the two angul pramana from the nipple. If an injury on stanrohit marma, blood is deposited in kostha (chamber) and thoracic cavity causes death due to kaas (cough) and shwas (congestion of the lungs).Here if pulmonary artery is injured, severe bleeding and lungs may collapse and death occurs. Therefore complete and detailed knowledge of Mamsa marma is important for any surgeon or physician.

(1)Talhridaya Marma- It is type of Mamsa marma. Its pramana (dimension)) is ardhangul.It is kalantar (in future) pranhar (life end) marma in nature. It is four in number, two in adhah shakha (lower extremities) and two in urdhwa shakha

(Upper extremities). ${ }^{7}$

Locations - It is situated in the middle of the sole of the foot $^{8}$ and palm. It is the centre of the sole and palm in front of the middle finger.

Anatomical structure- In adhah shakhagat (lower extremities), talhridaya marma-some structures are involved there such as ${ }^{9}$ - (a) Medial plantar artery (b) Lateral plantar artery (c) plantar nerve (d) plantar aponeurosis (e)Abductor hallucis muscles. In Urdhwa Shakhagata (upper extremities), talhridaya marma - Some structures are also involved ${ }^{10}$ such as(a) Flexor retinaculum (b) Palmar aponeurosis, (c) Palmaris brevis muscle, (d) interossei palmar muscle.

If an injury occurs in this marma area, pain may develop and finally pain ends into the death ${ }^{11}$. 
(2) Indräbasti - It is type of Mamsa marma. Its size is ardhangul and four in number. Two in the upper limb and two in the lower limb. It occurs in the calf muscles of the $\operatorname{leg}^{12}$ and flexor muscle of the forearm, where the ulnar and the radial nerve are present. Location- Indrabasti marma is situated in the middle of the jangha (leg) ${ }^{3}$ and the middle of the forearm.

Anatomical structure - It includes many structures such as - (a) pronator teres (b) Flexor carpi radialis (c) Palmaris longus (d) Flexor carpi ulnaris (e) Flexor digitorum superficialis, (f) Radial artery and ulnar artery,(g)Median nerve and ulnar nerve. If Injury occurs in this marma area, results in excessive haemorrhage and finally ${ }^{14}$ ends into the death.

(3) Guda marma - Guda is the terminal portion of the brihat antra (large intestine) and is responsible for the evacuation of faeces and flatus from the body ${ }^{15}$. It is one in number and four angul in size. This is an udara Mamsa marma and sadyah (immediate) pranhar marma. It is the end part of the alimentary canal.

Location- It is situated in between both the lower limbs towards back side. It has a width of four fingers, $4-5 \mathrm{~cm}$ in length.

Anatomical structure- $G u d a$ is very much correlated to the rectum rather than concerned only with the anus. The structure involves which may be (a) Bulks of levator ani muscle (b) Transverse peronei muscle (c) The sphincter ani muscle

Some branches of haemorrhoidal veins are embedded in the mucous membranes of the rectum and related to the anus ${ }^{16}$. Injured anus ends into death within twenty-four hours of hurt ${ }^{17}$ due to severe bleeding.

(4) Stanrohita marma- It is type of Mamsa marma. It is two in number and ardhangul in size. It is an urah mamsa marma. It is kalantar pranhar marma, but sometimes it behaves as sadyah pranhar marma due to collapse of lungs and severe bleeding after the damage of pulmonary artery.

Location- It is situated above stanmool marma with the length of two fingers of width $(2-3 \mathrm{cms}$.) Anatomical structure - The areolar space is referred for the stanrohit marma, this covers the underlying mammary glands and the surrounding tissues. Despite the adequate vascular supply, this is the less sensitive area than the stanamool.

In the modern view, many anatomical structures are involved in this marma such as (a) pectoralis minor muscle (b) Intercostal muscle, (c) intercostal nerves (d) Internal thoracic artery.

If trauma occurs on stanrohit marma and pulmonary artery is injured, causing severe haemorrhage, the lungs collapse and ultimately death due to kaas (cough) and Shwas ${ }^{18}$ (congestion of the lungs).

\section{SUMMARY AND CONCLUSION}

It is concluded that Mamsa marma is very important to all physicians and surgeons for treatment. Trauma or attack of Mamsa marma can cause pain, severe bleeding or may death. This concept of Mamsa mar$m a$ is more helpful to protect certain parts of the body.

\section{REFERENCES}

1. Sushruta Samhita (Ancient literature), Sharir Sthan (study of body), kaviraj Ambika datt shashtri, Varanasi, Chaukhamba Sanskrit Sansthan, p-67, 6/3.

2. Sushruta Sharir sthan (study of body), p-67,Prof. purnchandra Jain and Dr.Pramod Malveey, A textbook of human anatomy (Hindi), Marma Sharir, Varanasi, chaukhamba.(publication)

3. Dr.Bhaskar Govind Ghanekar, Sushrut Sharir,Shan (tikakara or commentator), B.H.U, U.P, p-191,

4. Dr. Bhaskar Govind Ghanekar, Sharir Sthan, P-183,

5. Sushruta Samhita, Sharir Sthan, Kaviraj Ambika datt shashtri, Choukhamba Sanskrit Sansthan 2004, Varanasi. P-67.

6. Prof. D.G Thatte editor, Marma Sharir 594, Sushruta Samhita Sharirsthan, Dr Bhaskar Govind Ghanekar commentary, Meharchand Lachhamandas publications 2008.

7. Prof. D. G, Thatte, editor Marma Sharir P- 594, Dr B. G. Ghanekar commentary, (Sushrut-.Sharisthan)

8. Prof. D. G, Thatte editor Marma sharir, P-595, B.D. Chaurasia volume 1 and 2, eighth edition.

9. Prof. D. G Thatte, editor, Marma Sharir- p-595, Prof. Purnchandra Jain and Dr Pramod Malveey, A textbook of human anatomy, Marma Sharir, P-453. 
10. Prof. D. G Thatte, editor Marma Sharir, P-595, B.D Chaurasia human Anatomy volume $1 \& 2$

11. Sushruta Samhita Ssharir Shan, Ambika datt shashtri, Chaukhamba Sanskrit publicationp-72, Dr.B.G, Ghanekar Sharir Sthan. Pratyekmarmanirdesham Shariram.

12. Sushruta Sharir sthan, p-72, 6/25, Dr Bhaskar Govind Ghanekar, Sharirsthan (study of body), commentary. p- 191.Prof, D.G, Thatte editor, Marma Sharir, P-596

13. Prof. D. G Thatte, editor, Marma Sharir, p-596, Dr B. G. Ghanekar, Sharir sthan p-191.

14. Prof. D. G Thatte, editor, Marma Sharir, p-596, Dr. B. G Ghanekar, Sharir Sthan. P-193.

15. Prof. D. G, Thatte, editor, Marma Sharira P-598, Dr. B. G. Ghanekar, Sharir Sthan, p-193

16. Prot. D.G. Thatte, editor, Marma Sharir, P-598, Dr. B.G. Ghanekar, Sharir Sthan. P-193

17. Prof. D. G Thatte, editor, Marma Sharira, P-600, Chaukhambh, Dr. B. G Ghanekar, sharirsthan, P-195.

18. Prof. D. G, Thatte, editor Marma Sharir, P-600, Pratyekmarmanirdeshshariram, Dr. B. G. Ghanekar Sharir Sthan, P-195.

\section{Source of Support: Nil Conflict of Interest: None Declared}

How to cite this URL: Mahesh Kumar et al: Concepts Of Mamsa Marma - A Review Article. International Ayurvedic Medical Journal \{online\} 2021 \{cited September 2021\} Available from: http://www.iamj.in/posts/images/upload/2209_2212.pdf 